\title{
A RETROSPECTIVE STUDY OF HISTOPATHOLOGICAL FINDINGS IN 894 CASES OF MEGACOLON. WHAT IS THE RELATIONSHIP BETWEEN MEGACOLON AND COLONIC CANCER?
}

\author{
Sérgio Britto GARCIA(1), Alexandre Luis ARANHA(1), Fabio Rogério Brosci GARCIA(1), Filipe Volpe BASILE(1), André Péra Marques PINTO(1),
}

Enio Chaves de OLIVEIRA(2) \& Sérgio ZUCOLOTO(1)

\begin{abstract}
SUMMARY
Patients with megaesophagus (ME) have increased prevalence of cancer of the esophagus. In contrast, a higher incidence of colorectal cancer is not observed in patients with megacolon (MC). MC is very common in some regions of Brazil, where it is mainly associated with Chagas disease. We reviewed the pathology records of surgical specimens of all patients submitted for surgical resection of MC in the Hospital das Clínicas of the Faculty of Medicine of Ribeirão Preto (HC-FMRP), from the University of São Paulo. We found that 894 patients were operated from 1952 until 2001 for MC resection. Mucosal ulcers, hyperplasia and chronic inflammation were frequently found, while polyps were uncommon. No patients with MC presented any type of colonic neoplasm. This observation reinforces the hypothesis that MC has a negative association with cancer of the colon. This seems to contradict the traditional concept of carcinogenesis in the colon, since patients with MC presents important chronic constipation that is thought to cause an increase in risk for colon cancer. MC is also associated with other risk factors for cancer of colon, such as hyperplasia, mucosal ulcers and chronic inflammation. In ME these factors lead to a remarkable increase in cancer risk. The study of mucosal cell proliferation in MC may provide new insights and useful information about the role of constipation in colonic carcinogenesis.
\end{abstract}

KEYWORDS: Megacolon; Megaesophagus; Chagas disease; Colon cancer.

\section{INTRODUCTION}

Chagas disease is caused by the hemoflagellate Trypanosoma cruzi. The infection has an acute phase that lasts for two months and the patient may present a few non-specific symptoms. Afterwards the patient goes into chronic phase of the disease that is defined by positive serological tests. Most infected people remain asymptomatic for life. After a period of one to two decades in chronic phase, usually, $7-10 \%$ of patients will show digestive manifestations. Megaesophagus (ME) and megacolon (MC) are the most important disturbances of the digestive form of Chagas disease. Physiopathology of ME and MC is attributed to the destruction of neural cells of the enteric plexuses of the digestive tube ${ }^{5}$ and the process of neurons destruction is related to nitric oxide ${ }^{8}$. Motility disturbances and achalasia of internal anal sphincter lead to latter enlargement of the colon and constipation. The rectum and the sigmoid colon are the most compromised segments. Clinically patients with chagasic megacolon present severe and prolonged constipation of many days (up to 60 days) for decades. Literature has reported constipation as an important factor in the pathogenesis of colorectal cancer because it prolongs the contact of carcinogens in the stools with the mucosa ${ }^{13,14,16}$. Conversely, a higher incidence of colorectal cancer is not observed in patients with megacolon. In fact there is a long-standing observation among many Brazilian physicians that carcinoma of the colon is unlikely to occur in chagasic
MC. Recently it has been published one case of association between colon cancer and $\mathrm{MC}^{2}$; in this article the authors also report a large review of the literature that confirms a low frequency of this association. There is also a recent report of two patients with chagasic MC that presented adenocarcinomas, but in these cases the tumours were not actually located in the dilated segment of the colon ${ }^{23}$. Furthermore, none of the few other retrospective studies on complications of MC mention cases of cancer ${ }^{9,10,15,18}$. These studies report a small number of cases and, for this reason, it is difficult to gather enough collective information to produce meaningful data on this issue. In order to provide additional data and to contribute to a more comprehensive assessment and understanding of the association between cancer and MC, we reviewed the pathology records of surgical specimens of all patients submitted to colectomy due to the presence of MC in the Hospital of the Faculty of Medicine of Ribeirão Preto (FMRP), University of São Paulo. This is a major reference hospital for patients with Chagas disease, and is located at the centre of an old and heavily endemic region for Chagas disease.

\section{MATERIAL AND METHODS}

We reviewed the pathology records of surgical specimens of all patients submitted for surgical resection of MC in the HC-FMRP from 1955 to 2001 in the HC-FMRP. The data recorded until 1998 were: 


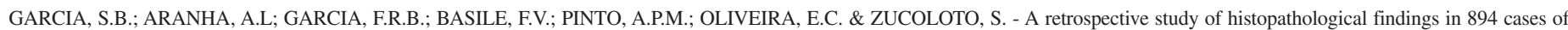
megacolon. What is the relationship between megacolon and colonic cancer? Rev. Inst. Med. trop. S. Paulo, 45(2):91-93, 2003.

number of cases, causes, sex, age and histopathological findings. From 1999 to 2001 we performed a study for the number of cases of MC and a search for the presence or absence of cancer in then.

\section{RESULTS}

A total of 802 patients were operated for MC resection from 1955 to 1998 at our Institution. Of these patients, $95.4 \%$ were chiasmic, 1.2\% had congenital MC and 3.4\% had unknown causes of MC. The patients ranged in age from 1 month to 80 years, but $70 \%$ of them were older than 45 years (Table 1). Men were less often affected than women (42\% against $58 \%$, respectively). In the present study no patients with MC presented cancer of the colon. Histopathological alterations frequently found were: mucosal hyperplasia (found in $54.8 \%$ of patients) ulcers $(12.0 \%)$, chronic inflammation $(28.3 \%)$ and atrophic mucosa $(2.6 \%)$. Intestinal polyps were uncommon and found in only 3 patients $(0.4 \%)$.

Ninety-two patients were operated for MC resection from 1999 to 2001. None of them presented any type of colonic malignant neoplasm.

Table 1

Age distribution of patients with megacolon, from 802 patients operated for megacolon resection in the Faculty of Medicine of Ribeirão Preto, University of São Paulo, Brazil, from 1955 to 1998

\begin{tabular}{cc}
\hline Age & Number of cases of megacolon \\
\hline$<20$ & 22 \\
$20-29$ & 62 \\
$30-39$ & 163 \\
$40-49$ & 244 \\
$50-59$ & 195 \\
$60-69$ & 94 \\
$>70$ & 22 \\
\hline Total & 802 \\
\hline Mean & 46.01 \\
\hline
\end{tabular}

\section{DISCUSSION}

The study of the association between cancer and acquired MC may provide useful data to clarify the pathogenesis of colonic cancer ${ }^{17}$. Our observation reinforces the concept that $\mathrm{MC}$ has a negative association with cancer of the colon. It is also in accordance with our previous experimental observation of reduced frequency of colon tumours in rats with MC treated with carcinogens ${ }^{7}$. This seems to contradict the traditional concept of carcinogenesis in the colon, since patients with $\mathrm{MC}$ have various risk factors for colon cancer. First of all, they have important chronic constipation that has been considered as a risk factor for cancer, as it provides a longer contact of dietary carcinogens with the mucosa ${ }^{3}$. Furthermore, most of the cases of MC are located in the distal portion of the large bowel ${ }^{9}$, where the cancer of colon is more commonly found, and most of the patients are over fifty years old, and, therefore, belong to a age group of major risk for colon cancer. Finally it is considered that mucosal hyperplasia, ulcers and chronic inflammation are factors that increase the risk for cancer in many organs. In ME these factors, associated with luminal stasis, lead to a remarkable increase in cancer risk ${ }^{29}$. Since the nineteenth century the literature has demonstrated a significant positive association between esophageal cancer and ME that has been extensively confirmed in more recent studies ${ }^{25,28,29}$. There is also a report of a patient that presented leiomyosarcoma of the esophagus with chagasic megaesophagus ${ }^{1}$. In a review in the FMRP, we found a frequency of $3.1 \%$ of esophageal cancer in 364 patients operated for ME resection (unpublished data). Interestingly it has been recently observed that there appears to be a positive association between Chagas disease and uterine leiomyoma ${ }^{19}$.

Thus, the relationship between T.cruzi infection and cancer incidence is rather complex. It is known that $T$. cruzi produces persistent chronic inflammatory process along the digestive tube with uneven distribution ${ }^{27}$. Some chronic infections by viruses, bacteria and parasites are well known as risk factors in human cancers ${ }^{11}$. Why chronic infection by T.cruzi does not behave similarly? Molecular mechanisms involved in carcinogenesis related to chronic inflammation are not well understood. Recent data suggest a possible role of the nitric oxide ${ }^{6}$ in the multistep carcinogenesis mechanism ${ }^{6}$ that may be also shared in some way by chronic T. cruzi infection ${ }^{7,21}$. It has been reported that rats chronically infected with $T$. cruzi have a lower incidence of 1,2-dimethylhydrazineinduced colon cancer ${ }^{22}$ and infection by $T$.cruzi can cause important tumoricidal effect ${ }^{4}$. Similarly, it has been reported that some protozoans such as Toxoplasma gondii and Besnotia jellisoni may increase resistance against tumor ${ }^{12}$. Thus, a striking possible role of $T$. cruzi infection against the development of tumours by increasing the immune resistance is stimulated by our study.

The apparent negative correlation between human MC and colon cancer needs to be confirmed by further larger studies, preferably prospective and multidisciplinary. It also highlights the necessity for more research on the role of constipation in increasing colon cancer risk, which remains controversial, with some studies dismissing $i^{13,24}$ and others supporting it ${ }^{16,20,26}$. Our data add weight to the view that constipation is at least not always related to increased risk of colon cancer. Since constipation is highly prevalent in many countries and many clinical and nutritional attitudes are based in accepting its role as a risk factor for colon cancer, this aspect deserves more attention in basic and clinical research.

\section{RESUMO}

\section{Um estudo retrospectivo dos achados histopatológicos em 894 casos de megacólon. Qual é a relação entre megacólon e o câncer de cólon ?}

Pacientes com megaesôfago (ME) possuem incidência aumentada de câncer de esôfago. Em contraste, há poucos relatos na literatura de associação entre megacólon (MC) e câncer de cólon. O MC é muito comum em algumas regiões do Brasil, e na maioria das vezes, está associado à Doença de Chagas. Nós reavaliamos os arquivos de patologia de peças cirúrgicas de todos os pacientes submetidos à ressecção de MC no Hospital das Clínicas da Faculdade de Medicina de Ribeirão Preto (HC-FMRP), da Universidade de São Paulo. Encontramos o número de 894 pacientes que foram operados de 1952 até 2001 para a ressecção do MC. Úlceras da mucosa, hiperplasia e inflamação crônica foram frequentemente encontrados, enquanto pólipos foram incomuns. Nenhum 


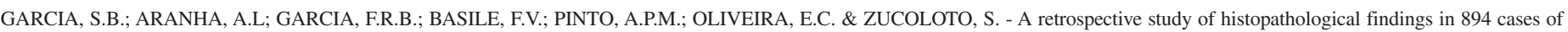
megacolon. What is the relationship between megacolon and colonic cancer? Rev. Inst. Med. trop. S. Paulo, 45(2):91-93, 2003.

paciente com MC apresentou qualquer tipo de neoplasia do cólon. Essa observação reforça a hipótese de que o MC tem uma associação negativa com câncer de cólon. Isso parece contradizer o conceito tradicional de carcinogênese do cólon, uma vez que pacientes com MC apresentam constipação crônica importante, a qual é tida como uma causa que aumenta o risco de câncer de cólon. MC também está associado a outros fatores de risco para o câncer de cólon, como hiperplasia, úlceras da mucosa e inflamação crônica. No megaesôfago (ME), tais fatores aumentam o risco de câncer esofágico. $\mathrm{O}$ estudo da proliferação celular da mucosa no MC pode fornecer informações úteis sobre o papel da constipação na carcinogênese colônica.

\section{REFERENCES}

1. ADAD, S.J.; ETCHEBEHERE, R.M.; HAYASHI, E.M. et al. - Leiomyosarcoma of the esophagus in a patient with chagasic megaesophagus: case report and literature review. Amer. J. trop. Med. Hyg., 60: 879-881, 1999.

2. ADAD, S.J.; ETCHEBEHERE, R.M.; ARAÚJO, J.R. et al. - Association of chagasic megacolon and cancer of the colon: case report and review of the literature. Rev. Soc. bras. Med. trop., 35: 63-68, 2002.

3. BURKITT, D.P. - Cancer of the GI tract: colon, rectum, anus. Epidemiology and etiology. J. Amer. med. Ass., 231: 517-518, 1975.

4. CABRAL, H.R.A. - The tumoricidal effect of Trypanosoma cruzi: its intracellular cycle and the immune response of the host. Med. Hypotheses, 54: 1-6, 2000.

5. FARIA, C.R.; MELO-SOUZA, S.E.; RASSI, A. \& LIMA, A.F. - Evidências eletromiográficas de desnervação motora em pacientes na fase aguda da doença de Chagas. Rev. goiana Med., 25: 153-155, 1979.

6. FEIG, D.I.; REID, T.M. \& LOEB, L.A. - Reactive oxygen species in tumorigenesis Cancer Res., 54 (7 suppl.):1890s-1894s, 1994

7. GARCIA, S.B.; OLIVEIRA, J.S.M.; PINTO, L.Z.; MUCCILLO, G. \& ZUCOLOTO, S. - The relationship between megacolon and carcinoma of the colon: an experimental approach. Carcinogenesis, 17: 1777-1779, 1996.

8. GARCIA S.B.; PAULA, J.S.; GIOVANNETTI, G.S. et al. - Nitric oxide is involved in the lesions of the peripheral autonomic neurons observed in the acute phase of experimental Trypanosoma cruzi infection. Exp. Parasit., 93: 191-197, 1999.

9. GATTUSO, J.M.; KAMM, M.A. \& TALBOT, I.C. - Pathology of idiopathic megarectum and megacolon. Gut, 41: 252-257, 1997.

10. HENRY, M.A.C.A.; MENDES, E.F.; PRADO, R.G. et al. - Megacólon: análise de 200 pacientes submetidos a tratamento cirúrgico. Rev. goiana Med., 35: 25-33, 1989.

11. HERRERA, L.A. \& OSTROSKY-WEGMAN, P. - Do helminths play a role in carcinogenesis? Trends Parasit., 17: 172-175, 2001.

12. HIBBS Jr., J.B.; LAMBERT Jr., L.H. \& REMINGTON, J.S. - Resistance to murine tumors conferred by chronic infection with intracellular protozoa, Toxoplasma gondit and Besnoitia jellisoni. J. infect. Dis., 124: 587-592, 1971.
13. JACOBS, E.J. \& WHITE, E. - Constipation, laxative use, and colon cancer among middleaged adults. Epidemiology, 9: 385-391, 1998.

14. KUNE, G.A.; KUNE, S.; FIELD, B. \& WATSON, L.F. - The role of chronic constipation, diarrhea, and laxative use in the etiology of large-bowel cancer. Data from the Melbourne Colorectal Cancer Study. Dis. Colon Rect., 31: 507-512, 1988.

15. LANE, R.H.S. \& TODD, I.P. - Idiopathic megacolon: a review of 42 cases. Brit. J. Surg., 64: 307-310, 1977.

16. LE MARCHAND, L. - Constipation and colon cancer. Epidemiology, 9: 371-372, 1998

17. LOPES, E.R. - Megaesôfago, megacólon e câncer. Rev. Soc. bras. Med. trop., 21: 9194, 1988.

18. MENESES, A.C.O.; LOPES, M.A.B.; ROCHA, A. et al. - Megas e câncer. Câncer de intestino grosso em chagásicos com megacólon. Arch. Gastroent. (S. Paulo), 26: 13-16, 1989.

19. MURTA, E.F.; OLIVEIRA, G.P.; PRADO, F.O. et al. - Association of uterine leiomyoma and Chagas'disease. Amer. J. trop. Med. Hyg, 66: 321-324, 2002.

20. NAKAMURA, G.J.; SCHNEIDERMAN, L.J. \& KLAUBER, M.R. - Colorectal cancer and bowel habits. Cancer, 54: 1475-1477, 1984.

21. NY, L.; PERSSON, K.; LARSSON, B. et al. - Localization and activity of nitric oxide synthases in the gastrointestinal tract of Trypanosoma cruzi infected mice. J. Neuroimmunol. (Amst.), 99: 27-35, 1999.

22. OLIVEIRA, E.C.; LEITE, M.S.B.; MIRANDA, J.A.R. et al. - Chronic Trypanosoma cruzi infection associated with low incidence of 1,2-dimethylhydrazine-induced colon cancer in rats. Carcinogenesis, 22: 737-740, 2001.

23. OLIVEIRA, E.C.; LEITE, M.S.; OSTERMAYER, A.L.; ALMEIDA, A.C. \& MOREIRA, H. - Chagasic megacolon associated with colon cancer. Amer. J. trop. Med. Hyg., 56: 596-598, 1997.

24. POTTER, J.D. - Nutrition and colorectal cancer. Cancer Causes Control, 7: 127-146, 1996.

25. SANDLER, R.S.; NYREN, O.; EKBOM, A. et al. - The risk of esophageal cancer in patients with achalasia. A population-based study. J. Amer. med. Ass., 274: 13591362, 1995.

26. SONNENBERG, A. \& MULLER, A.D. - Constipation and cathartics as risk factors of colorectal cancer: a meta-analysis. Pharmacology (Basel), 47 (suppl. 1): 224-233, 1993.

27. TAFURI, W.L.; LIMA PEREIRA, F.E.; BOGLIOLO, L. \& RASO, P. - Lesões do sistema nervoso autônomo e do tecido muscular estriado esquelético na fase crônica da tripanosomose cruzi experimental. Estudos ao microscópico óptico e eletrônico. Rev. goiana Med., 25: 61-67, 1979.

28. WYCHULIS, A.R.; WOOLAM, G.L.; ANDERSEN, H.A. \& ELLIS Jr., F.H. - Achalasia and carcinoma of the esophagus. J. Amer. med. Ass., 215: 1638-1641, 1971.

29. ZUCOLOTO, S. \& REZENDE, J.M. - Mucosal alterations in human chronic chagasic esophagopathy. Digestion, 47: 138-142, 1990.

Received: 20 August 2002

Accepted: 12 February 2003 